\title{
The efficacy of law enforcement in the Tolaki Mekongga Indigenous Law Community's adultery (Umoapi) Resolution Process
}

\author{
Hasdin Yadin ${ }^{1 *}$, Haeranah¹, Hijra Adhiyanti Mirzana ${ }^{1}$ \\ ${ }^{1}$ Faculty of Law, Hasanuddin University, Indonesia \\ *Correspondence: hasdinyadin@gmail.com
}

\section{ARTICLE HISTORY \\ Received: 10.07.2021 \\ Accepted: 24.12.2021 \\ Published: 27.12.2021 \\ ARTICLE LICENCE \\ Copyright (C) 2021 The Author(s): This is an open-access article distributed under the terms of the Creative Commons Attribution ShareAlike 4.0 International (CC BY-SA 4.0)}

\section{Introduction}

Indonesia is a state of law, and the applicable laws are both written and unwritten. Written legal provisions are included in what is referred to as positive law. Positive law is present in both public and private law. Criminal law is a branch of public law. Indonesia's present criminal law is a codified criminal law, with the regulations gathered in a single set of laws known as the Criminal Code. Along with being codified, this portion of the legislation has been unified, which means that it now applies to all categories of people (Moeljatno,2009).

Customary law, as a law that exists and evolves inside society, cannot be divorced from society, since law appears alongside the community, as the expression "ubi societas ibi ius" indicates. Wherever there is a community, there is law. Thus, customary law is an expression of social and cultural ideals in action. Customary criminal law is a living law in society, in which the law identifies occurrences and behaviors that must be addressed (punished) because they have upset the social equilibrium (Samosir, 2013) (Salam, 2017).

The Tolaki Mekongga customary law group, which has occupied the majority of the peninsula of Southeast Sulawesi Province for a long period of time, holds a great regard for the customary regulations passed down through generations. Their forefathers' tradition of respect for customary law is still very much alive in the society, as demonstrated by the Tolaki Mekongga Tribe. the incorporation of Kalosara customs into the Tolaki Mekongga tribal community's system of legal norms and values (Toasa, 2015).

In this sense, one of the laws that contribute to the execution and attainment of national development goals is customary criminal law, which is considered to be one of Indonesia's positive legal systems. The 1945 Constitution Article 5 paragraph (3) letter (b) and Emergency Law No. 1 of 1951 aboutinterim measures to arrange the unity, structure, powers, and processes of civil courts provide the legal foundation for the application of the customary criminal law system. In Law No. 48 of 2009 on Judicial Power, the presence of customary criminal law as unwritten law is recognized (Mulyadi, 2013). 
The legitimacy of customary law is demonstrated by the fact that Indonesian laws and regulations acknowledge its existence. This recognition of customary law is spelled out in Article 18 B paragraph (2) of the 1945 Constitution, which states: "The state recognizes and respects customary law community units and their traditional rights for as long as they remain viable and in accordance with community developmentand the Unitary State of the Republic of Indonesia's principles." Indonesian Republic, which is governed by legislation (Dara, n.d.).

Adultery is referred to as Umoapi in Tolaki Mekongga traditional law. Adultery is defined in the Criminal Code as an act of sexual intercourse in which one or both parties are bound by marriage. Meanwhile, in Tolaki Mekongga's customary law, the term adultery or umoapi refers to more sophisticated acts of adultery that are not confined to marital status, with varying degrees of umoapi resulting in varying classifications and punishments.

According to local customary law, whenever a conflict occurs in a community, if it is resolved according to custom, the community's life will remain well established and maintained, eliminating hatred and vengeance in the hearts of those who are at odds. However, if the conflict is resolved according to criminal law, the community's life will always be a prolonged conflict, because communities in conflict will always be in conflict with one another. Peohala customary penalties are one method of settling disagreements, particularly in the case of adultery (Umoapi). Whereas in the Tolaki language's philosophy, "inae kona sara ie pinesara, inae lia sara ie pinekasara" means (who loves the presence of customs will be honored in a custom, while who does not respect a custom would be treated poorly, harshly) (Abdurrauf, 1993).

Settlement of conflicts between victims/families and perpetrators as a result of the occurrence of traditional moral offenses through the use of Kalosara as a symbol to unify people in conflict. For the Tolaki Mekongga people, honoring, considering sacredand sacred kalosara means adhering to their ancestors' lessons, and doing otherwise means they will be wicked, disobedient, and will suffer calamities.

To this day, decisions reached through the resolution procedure for adultery (umoapi) by customary speakers (tolea) are legitimate in the Tolaki Mekongga tribal community. Based on the above, the writers are interested in delving more into the subject through a scientific paper named "The Mechanism of Settlement of the Crime of Adultery (Umoapi) in the Tolaki Mekongga Indigenous Law Community."

\section{Methodology}

This study is an empirical legal study based on primary data (results from field research). Empirical legal research is a field study technique that involves monitoring and observing what is happening in the field, such as how these rules are applied in practice as society evolves and develops. Empirical legal study focuses on legal difficulties as a result of the gap between the imperatives, especially orders and prohibitions (das sollen), included in various laws and regulations and what really occurs based on apparentfacts (Das Sein). In addition, normative research using a legal perspective is utilized to complement this empirical research by performing a study of the laws and regulations pertaining to customary criminal law.

\section{Result}

As we have seen, the fundamental meaning of Kalosara in terms of dispute resolution, particularly the settlement of adultery cases among indigenous peoples of the Tolaki Mekongga Tribe in Kolaka Regency, Southeast Sulawesi Province, is that people will generally prefer to have their disputes resolved through this alternative dispute resolution mechanism, namely the Kalosara instrument. This Kalosara instrument plays a significant role in the community's social order, such that when there is a conflict in the lives of members of the Tolaki Mekongga tribal community, this Kalosara instrument acts as the primary element and driving force of the alternative dispute resolution process itself (Suud, nd)

Tolaki Mekongga customary law, referred to as "Sara," is symbolized by an object or characteristic called Kalo or, more frequently, Kalosara, which serves as the primary element and driving force for alternative conflict settlement in the Tolaki Mekongga tribal group. The legal values contained in Kalosara enable the community to resolve cases, particularly those involving adultery, through an alternative dispute resolution process in which the elements of the Mekongga customary assembly institution, consisting of the Customary Council, Tonomotu'o, and Tolea Pabitara, use active and direct Kalosara instruments. Without this custom, alternative dispute resolution in the Tolaki Tribe community will likewise be ineffective.. 
In the instance of adultery, which occurs frequently in the society, the customary speaker (tole) presents the culprit and the victim, with Puutobu, Tonomotu'o present as well. The process for settlement and the imposition of customary fines will be communicated in the presence of the culprits' and victims' families. Traditional holders of Sara Wonua (the country's customary law) and traditional speakers (tolea) are required to wear oversized traditional clothing when resolving disputes between citizens, both in terms of customary criminal acts and customary civil matters, using generations-old procedures and habits.

In the Tolaki Mekongga community, mechanisms or procedures for settling customary criminal actions and customary civil proceedings usually include kalosara. Customary authorities preserve the processes and customs, which include the following:

a) Puutobu, as the regional customary leader at the sub-district (district) level, is sometimes doubled by the Camat serving as chairman of the adat court session in his area, which supervises numerous adat leaders at the village or village/kelurahan level;

b) One or more Toono Motuo individuals, meaning traditional Tolaki village/kelurahan leaders who are now held concurrently by the Village/Kelurahan Head serving as members of the customary assembly;

c) A Pabitara (customary spokesman) is a member of the customary assembly who represents the interests of the women's family in times of conflict.

d) A Tolea, particularly a traditional Tolaki leader who serves as a member of the customary assembly and is responsible for transmitting, defending, and reporting the customary assembly's findings to the man's family;

e) Tamalaki (traditional court security officer/in the past, functioned as warlord) is tasked with the responsibility of ensuring the fair trial of customary criminal proceedings.

According to the opinion above, in every trial for resolving customary criminal and customary civil cases in the Tolaki tribal customary law community, the role of customary speakers (tolea) is extremely active in utilizing kalosara based on procedures or procedures and customs in the Mekongga traditional assembly, which serves as a customary institution that accommodates traditional instruments. From the victim's standpoint, the tolea pabitara (customary speaker) aims for two (two) objectives during this peace process, namely:

1. Agreement between the victim/family and tolea pabitara to abstain from violent retaliation against the offender or the perpetrator's relatives.

2. Agreementbetween Tolea Pabitara and the victim's representation/family representative on the different forms of peohala (sanctions) that can be imposed on the perpetrator, including peohala mohewu and peohala owose.

According to the perpetrators of the Umoapi customary crime, the Tolea Pabitara agreement with the perpetrators'/his relatives' representatives seeks two (two) objectives in this peace process, namely:

1. The culprit or his family members bearfull responsibility for their crimes and do not flee.

2. The culprit or his family prepares all responsibilities that will be subject to customary punishment for peohala (peohala mohewu or peohala owose), as well as papers for customary court proceedings.

The tolea pabitara (customary speaker) who has reached an agreement with the victim's envoy or family, as well as the agreement reached between the tolea pabitara and his envoy or family, should promptly inform the puutobu. Puutobu then conveyed the parties' wish for peace to government authorities such as the sub -districthead or village/kelurahan head via the traditional leaders of Puutobu as regional customary rulers (at the sub-district level). At the district or village/kelurahan level, the chairman of the Mekongga customary council takes action to ensure that the procedure for peaceful dispute settlement is carried out quickly, so that the victim's/his family relationship with the perpetrator's/his family does not break.

The following procedures must be followed when resolving disputes arising from the occurrence of the Umoapi customary offense through the Mekongga customary assembly:

a. The customary head (puutobu), who is also the village head, sends a tolea pabitara (spokesperson) to meet with the perpetrator/his family and a tolea pabitara (spokesperson) to meet with the victim/family. The perpetrator/his family sent charismatic and respected parents to represent the peace event, as did the victim/his family. Both Tolea 
Pabitara must simultaneously inquire whether the envoys from each party are willing to meet in a traditional manner as a kind of peace, as there is no assurance that the victim's family will seek retribution against the offender.

b. If the victim's representative and the perpetrator's representative agree to meet, Tolea Pabitara, in collaboration with the chairman of the local Mekongga customary council, shall develop an implementation strategy that serves as an additional mediator in resolving the victim's/his family's conflict with the perpetrator's/his family's conflictas a result of the customary crime that occurred.

c. Each Tolea pabitara works as a mediator between the parties to the dispute and their representatives in determining the day and date of the peace ceremony.

d. Tolea pabitara through the use of Kalosara to contact delegates representing the disputing parties and all their relatives considered necessary to attend and participate in the peace ceremony.

e. The peace event is often held at Toono Motuo's or Puutobu's residence. The peace ceremony was attended by the puutobu, the chairman/member of the Mekongga sub-district and village/kelurahan customary council, toono motuo, tolea pabitara, and local government officials such as the Camat, Village Head, Lurah, Babinsa, and Bhabinkamtibmas.

f. After both parties' envoys agreed to participate in the peace event, Tolea Pabitara lifted Kalosara and placed it slowly and wisely in front of all parties present, first obtaining permission from the local government officials present and from the two parties' envoys that the peace event would begin shortly.

g. Delegates from both sides who are experiencing difficulties are invited to bring up concerns of customary offenses that cause the victim/his family to clash with the perpetrator/his family.

h. therefore it is appropriate for tolea pabitara to advance notions of conflict settlement based on mediation principles that allow both parties to acceptor agree to itgenuinely and willingly through their envoys. Tolea pabitara, as a traditional spokesman, must be capable of expressing an evaluation of the customary crimes that happened and the repercussions of conflicts between the victim/his family and the perpetrator/his family withoutcondemning one party.

Provide an explanation of the meaning, comprehension, and possibility of all dangers or negative consequences that may arise for someone involved in a dispute who refuses to comply with the direction of traditional leaders in peace and the decisions of traditional speakers (tolea) in the customary court session facilitated by the Mekongga customary assembly. The customary court session will follow a dais format.

Propose an operationalized idea for resolving disputes arising from customary illegal actions, which must be able to persuade both parties to the issue (represented by their respective representatives) to truly embrace a peaceful resolution.

1) The perpetrator/his family agrees to meet all demands made by the victim/his family in accordance with the Tolaki Mekongga customary law; 2 . The parties agree to continue the dispute resolution process through a customary court trial for the imposition of the peohala on the boater/his family through his envoy.

2) The parties express their opposition to all types of violence, and the victim/family agrees not to exact physical retribution on the perpetrator/his/herfamily.

3) The disagreeing parties then shake hands through their envoys, indicating that there is no longer any animosity, resentment, or wrath associated with the Umoapi traditional crime's occurrences.

4) In the presence of delegates from both parties and the toono motuo, traditional leaders (Puutobu, Camat, or Village Heads/Kepala Kelurahan) provide directions that, in essence, agree with the intention of the customary spokesperson (tolea) and also with the disputing parties' wishes to make peace with sincerity. These directions will be continued during the trial of the customary court to pass the verdict.

\section{Discussion}

Legal effectiveness indicates that it will be highlighted in relation to the objectives to be accomplished, namely the law's efficacy. Generally, one of the measures done to ensure that the community adheres to the rule of law is to include punishments. These penalties may take the shape of negative or positive sanctions, with the goal of creating a stimulus to preventindividuals from engaging in vile or laudable behavior. 
If what is conveyed is unable to address the issues immediately confronting the intended recipient of legal communication, complications will arise. As a result, the legislation has little impact or perhaps has a detrimental effect. This is because their demands are unmet and unacknowledged, resulting in irritation, pressure, and even confrontation.

Legal awareness in society must constantly be fostered and ingrained in us that activities that violate the law will have legal consequences if committed.

It cannot be overlooked that one of the variables that contribute to the growth of community law is the community's legal knowledge and compliance with the law. Legal awareness is critical for a society's success since it is directly related to the strength and weakness of the community's legal compliance element. The lower the public's degree of legal knowledge, the less likely the community will comply with the law. Inversely, the more the community's legal knowledge, the greater the community's compliance, ensuring that the development process and the law's efficacy are felt directly by the community.

If we consider the notion of law in the modern era, the fundamental structure of the state must adapt to social circumstances. To provide order to social reality, the law is used to bond them. Citizens' allegiance to law is an endeavor to rediscover the established state's raison d'être, namely to safeguard individual liberty. To safeguard the individual's independence, the state enacts legislation as a means of establishing order.

To ascertain the following elements affecting law enforcement in relation to the method for resolving the offense of adultery (Umoapi) in the Tolaki Mekongga customary law community: 1) Legal factor; 2) Law enforcement factor; 3) Facility and facility-related factor; 4) Community factor; 5) Cultural factor

\subsection{Legal factors}

Regarding legal considerations. In this case, it is reflected in the Kolaka Regency Regional Regulation No. 11 of 2016 on Mekongga Indigenous Assembly Empowerment. Chapter five (V): Dispute resolution. Article 8 paragraph 1 establishes that conflicts within the Mekongga customary law community are handled by the Mekongga customary assembly, and paragraph 2 establishes that if mediation fails to achieve consensus, the matter may be brought before the courts. The article makes it clear that the rule of law applies to disputes within the Mekongga customary law community, but does not provide a more specific article regarding decency crimes, which will affect the customary speaker's (tolea) ability to carry out law enforcement in the Tolaki Mekongga customary law community.

\subsection{Law Enforcement Factor}

Law enforcement is connected to the parties that create and apply the law (law enforcement), and the components of law enforcement are customary speakers (tolea) who will be able to provide certainty, justice, and proportional legal benefits to the Tolaki Mekongga customary law community through the mechanism for resolving the crime of adultery (umoapi).

\subsection{Facility and Infrastructure-Related Factors}

The provision of facilities and infrastructure to assist law enforcement officials in doing their responsibilities is critical and influential in providing a system for addressing the offense of adultery (umoapi) in the Tolaki Mekongga customary law community. attain legal efficacy. In relation to the facilities and infrastructure referred to as these facilities, Soekanto (1983) predicts a benchmark for the effectiveness of specific elements of infrastructure, where the infrastructure must unambiguously contribute to the apparatus's smooth operation at the place or work location.

Along with providing equipment in each office or location where law enforcement officers perform their duties, one of the most critical aspects of providing a mechanism for resolving the crime of adultery (umoapi) for the Tolaki Mekongga customary law community is providing a traditional courthouse for customary speakers (tolea) to assist perpetrators and victims in settling and awarding the crime. Thus, it will maximize the perfo rmance of traditional speakers (tolea) in enforcing customary law in the Kolaka Regency region.

\subsection{Community Factor}

While law enforcement's primary goal is to maintain peace in society, individuals have differing views on what constitutes law. 
The system of norms that exists in the Tolaki Mekongga customary law community is that the community is obedient when itcomes to paying customary fines imposed by customary speakers (tolea), butwhen the perpetrator of adultery (umoapi) is given a marriage sanction, they were previously separated in the bondage.

That is, the law's efficacy is partly contingentupon society's willingness and awareness of the law. Due to the community's lack of understanding, law enforcement will face difficulties; thus, measures can be done to socialize the community by involving social layers, power holders, and law enforcers themselves. The law's formulation must also consider the link between societal change and the law, which must ultimately be effective as a way of controlling human conduct.

\subsection{Cultural Factor}

The legal culture (system) elemententails the values that underpin the relevantlaw, abstractnotions of what is deemed good (to be embraced) and what is considered evil (so to be avoided). Typically, these values are a pair of numbers that indicate two polar opposite circumstances that must be reconciled.

With values that are compatible with the local culture, it is hoped that there will be a reciprocal relationship between customary and positive law in Indonesia, such that the provisions in written legal articles will reflect the values that underpin customary law, allowing for the implementation of statutory law. Effectively apply. Then, it is anticipated that the harmony between the two values will also serve to set the law in its propercontext.

\section{Conclusion}

According to the research findings, the crime of adultery (umoapi) in the Tolaki Mekongga customary law community was addressed through the use of customary speakers (tolea) and the imposition of customary fines in the Tolaki Mekongga tribal group. The study identified five variables that harmed law enforcement's effectiveness in resolving the adultery (Umoapi) offense in the Tolaki Mekongga Indigenous Law Community, namely: 1) Legal factor; 2) Law enforcementfactor; 3) Facility and facility-related factor; 4) Community factor; 5) Cultural factor

\section{References}

Abdurrauf, T. (1993). Kebudayaan Tolaki. Seri Etnografi Indonesia. Jakarta: Balai Pustaka.

Dara, I. (n.d.). Eksitensi Hukum Adat Pidana Sebagai Hukum Positif Indonesia. Makassar: Pustaka Pena Press.

Moeljatno. (2009). Asas-Asas Hukum Pidana. JakartaR: Rineka Cipta.

Mulyadi, L. (2013). Eksistensi Hukum Pidana Adat di Indonesia:Pengkajian Asas, Norma, Teori, Praktik dan Prosedurnya. Jurnal Hukum Dan Peradilan, 2(2), 226-246.

Salam, S. (2017). Dispensasi Perkawinan Anak di Bawah Umur: Perspektif Hukum Adat, Hukum Negara \& Hukum Islam. Pagaruyuang Law Journal, 1(1), 110-124.

Samosir, D. (2013). Hukum Adat Indonesia. Bandung: Nuansa Aulia.

Soekanto, S. (1983). Penegakan Hukum. Bandung: Bina Cipta.

Toasa, A. (2015). Analisis Yuridis Eksistensi Tanah Walaka Masyarakat Hukum Adat Tolaki dalam Sistem Hukum Agraria Nasional. Universitas Islam Sultan Agung. 